\title{
Earmarks and Subcommittee Government in the U.S. Congress
}

\section{Austin Clemens', Michael Crespin², and Charles J. Finocchiaro ${ }^{3}$}

\begin{abstract}
In recent years, considerable scholarly attention has focused on earmarks, the quintessential example of pork barrel politics. We assess the degree to which existing theories can explain the distribution of earmarks in the U.S. House of Representatives. First, drawing on informal interviews with individuals on Capitol Hill regarding the earmark process, we argue that assessing institutional and constituency-level factors that affect the earmark receipts of individual members requires examination at the level of the Appropriations subcommittees. Second, we demonstrate that both distributive and partisan theories of legislative organization are applicable to the distribution of earmarks. Finally, we present results indicating that contrary to the conventional wisdom, most subcommittees do not distribute pork based on electoral vulnerability. Rather, legislators' status in the appropriations process has the most influence. These findings offer insights into the path forward as debate continues over congressionally directed spending.
\end{abstract}

ITexas A\&M University, College Station, USA

${ }^{2}$ The University of Oklahoma, Norman, USA

${ }^{3}$ University of South Carolina, Columbia, USA

\section{Corresponding Author:}

Charles J. Finocchiaro, University of South Carolina, Department of Political Science, 350 Gambrell Hall, Columbia, SC 29208, USA.

Email: finocchi@mailbox.sc.edu 


\section{Keywords}

Congress, distributive politics, earmarks, appropriations

Despite a recent lull in what had been a steady rise in the use of congressional earmarks, much remains to be learned about how the U.S. Congress distributes these funds. A long-standing literature in political science links pork, as a broadly defined legislative commodity, to the electoral interests of members of Congress (Stein \& Bickers, 1995). Moreover, recent scholarship argues that earmarks are a tool the majority party leadership employs to benefit its most vulnerable members (Lazarus, 2009). However, research generally treats the underlying mechanics in an amorphous way-rarely is the process precisely specified, and theoretical treatments and empirical analyses often gloss over important procedural aspects of congressional budgeting.

In this article, we use data from the appropriations bills for fiscal years 2008 and 2009 to demonstrate that the earmark process cannot be explained by just one theoretical perspective on legislative organization. First, we argue that committees led by "cardinals" and ranking members, as opposed to party leaders, dominate the distribution of earmarks, thus underscoring a committee-centric theory of legislative organization. However, this does not mean that parties are an unimportant part of the story - our data reveal that the majority party receives $60 \%$ of earmark dollars compared with only $40 \%$ reserved for the minority. Furthermore, we find little support for the argument that a disproportionate share of earmarks is provided to members in marginal districts. Yet we do find evidence supporting a simple distributive politics theory of universalistic lawmaking, because almost all representatives receive some earmark dollars.

In building our case, we advance understanding of the congressional pork barrel by wading into the structural mechanisms of earmark distribution in the U.S. House of Representatives to demonstrate the nuanced factors shaping who wins and who loses. Unlike prior studies that have typically focused on a specific category of earmarks or lumped all earmarks into an aggregate sum, we incorporate the fact that nearly all earmarks are added at the subcommittee level and test hypotheses using a research design that more closely mirrors the data-generating process (Morton, 1999). We contend that committee and subcommittee leaders not only benefit disproportionately in the earmark game, but that they are also the key players who determine how well their colleagues will fare. Our findings hearken back to a more integrated view of legislative politics in which "competing" theories all contribute to conceptualizing and explaining distributive outcomes. 
The article proceeds as follows. First, we discuss the relevant theories of legislative organization and develop expectations regarding the distribution of earmarks. In the next sections, we briefly review the extant literature on pork and discuss our perspective on resource allocation, which begins to fill a long-standing gap by probing the micro-level institutional dynamics that characterize the distribution of earmarks. The succeeding sections describe our data and present the empirical results, and we conclude with a discussion of the implications of our findings and some avenues for future research.

\section{Legislative Organization and Pork Barrel Politics}

For many years, scholars approached studies of the appropriations process from one of two broad perspectives - the distributive theory of legislative organization that explains outlays based on the electoral interests of individual members and partisan theories that posit a major role for the majority party in structuring legislative outcomes. More recently, research has begun to link these perspectives by finding commonalities among them.

\section{Distributive and Partisan Politics}

Briefly, distributive (or gains-from-exchange) theories were developed by Weingast (1979), Ferejohn (1986), Shepsle and Weingast (1987), and others, all of whom posit that the internal operations of Congress are designed to promote the distribution of policy benefits to electorally important constituencies. These theories describe a committee system that exists to facilitate logrolling across issue dimensions and to help solve the collective action problems inherent in a legislative body composed of members who want to vote with their districts to get reelected (Arnold, 1990; Mayhew, 1974). Furthermore, in an important addition to distributive theories, Weingast and Marshall (1988) argue that, because committees have gate-keeping power over their specific policy area and members have control over their committee seats due to the (no longer sacrosanct) seniority rule, logrolling will be institutionally supported. We believe that much of the earmark process follows this model, where committees are strong and power is dispersed among the chairs and ranking members.

Building on the distributive politics theories, Shepsle and Weingast (1981) develop a formal model to explain the universalism inherent in distributive politics that results from members' uncertainty over who will be part of future winning coalitions. Their model seeks to resolve the minimal winning coalition arguments made by Buchanan and Tullock (1962) and Riker (1962), as well as the empirical reality of universalism in various issue areas (Ferejohn, 
1974; Froman, 1967; Maass, 1951; Manley, 1970; Mayhew, 1974; Weingast, 1994). Our findings will shed light on this account of distributive politics as well, as we find that nearly all members who look to participate in the earmark process receive at least some of the pie.

We should note that a starting point of many of the distributive theories is that committees are often stacked with high demanders who accrue a greater than proportionate share of the "output" from the relevant committee. It is possible that this extra yield is primarily a function of the high demand for distributive goods on the part of the members on the committee rather than a result of the committee posts themselves. However, in the case of the Appropriations Committee, it is highly likely that many potential high demanders do not receive a slot on the committee. This is supported by Edwards and Stewart (2006) who use committee transfers to show that a seat on the Appropriations Committee is consistently among the mostly highly sought assignments in the House. Furthermore, the distributive theories also point out that high demanders are able to keep the larger share of earmarks due to institutional constraints inherent in the committee structure and House rules. This implies there is still something to be gained from the position itself.

In contrast to distributive theories of lawmaking stand Cox and McCubbins's $(1993,2005)$ cartel model and the conditional party government (CPG) theory of Rohde (1991) and Aldrich and Rohde (1998, 2000a, 2001), which posit a partisan theory of lawmaking in the U.S. House. ${ }^{1}$ Partisan models have been applied directly to the appropriations process as well (Aldrich \& Rohde, 2000b; Kiewiet \& McCubbins, 1985, 1991). Cartel theory tells us that the key to legislative success in Congress lies in controlling the agenda. Majority parties act as procedural cartels by exercising negative agenda control to ensure that no legislation will reach the floor that would split the party or move the status quo unfavorably with respect to a majority of its members. To make certain that such legislation does not receive a floor vote, rank-and-file members are expected to support the party on procedural votes (such as special rules votes in the House) in exchange for the possibility of securing a more powerful position in the institution and increasing the probability of maintaining (or achieving) majority status. Proponents of CPG argue that party strength is conditional on the homogeneity within each party and the heterogeneity between the two parties. When these two conditions are realized, rank-and-file members cede power to the leadership to enable them to "encourage" members to act in ways that further the party's goals. One way to stay in favor with the leadership is to vote with the party when needed on important legislation. If sending money to districts improves the chances of winning reelection-as posited by Mayhew 
(1974) - and hence remaining in the majority, then parties will have reason to make sure the bulk of these resources go to their members' districts.

\section{Theoretical Linkages, Subcommittee Context, and Expectations}

Balla, Lawrence, Maltzman, and Sigelman (2002) straddle the partisan and distributive literatures and find that the likelihood of receiving a pork barrel project is distributed evenly between the majority and minority parties in the House, although the majority enjoys an advantage in the dollar amount of earmarks accrued. Thus, the majority is insulated from blame for fiscal irresponsibility while maintaining an advantage in sending more home to their constituents than the minority. These findings, based on educational earmarks, help to reconcile the universalistic theories of distributive politics discussed previously with other majoritarian theories of lawmaking (Carsey \& Rundquist, 1999; Lee, 2000; Lee \& Oppenheimer, 1999; Levitt \& Snyder, 1995).

Recent work on pork barrel politics has incorporated insights from both partisan and distributive models as well as broadened theorizing to include other considerations such as geography, the implications of bicameral variation in electoral cycles, and cross-chamber differences among various types of pork (Clemens, Crespin, \& Finocchiaro, 2013, 2015; Crespin \& Finocchiaro, 2013; Evans, 2004; Frisch, 1998; Lee, 2003; Shepsle, Van Houweling, Abrams, \& Hanson, 2009). The growing literature on earmarks has, for various reasons, typically examined just a single type of earmark (e.g., Balla et al.'s, 2002, analysis of academic earmarks and Lee's, 2003, study of projects included in the 1998 transportation authorization bill) or pooled all earmarks irrespective of the appropriations bill in which the project was included (e.g., Engstrom \& Vanberg, 2010; Lazarus, 2009, 2010; Lazarus \& Steigerwalt, 2009; Shepsle et al., 2009). The primary interest of these research endeavors was to uncover broad partisan and/or electoral dynamics affecting the allocation of earmarks. And the resulting findings underscore the fact that the majority party often is advantaged, at least conditionally, in the distribution of pork. One of the key contingencies of the conditional findings involves electoral circumstance, as scholars have found that members facing a more challenging electoral environment are more focused on obtaining pork (Stein \& Bickers, 1995) and often receive a greater amount of pork than their more entrenched colleagues (Lazarus, 2009). According to Bickers and Stein (1996), this additional pork reduces the odds that a vulnerable incumbent will face a quality challenger in their next election. However, only some voters pay attention to pork awards, thus attenuating the usefulness of pork for reelection (Stein \& Bickers, 1994). It is also worth noting 
that Democrats tend to benefit more from traditional earmarks whereas Republicans are rewarded for other types of federal spending (Alvarez \& Saving, 1997; Crespin \& Finocchiaro, 2013; Lazarus \& Reilly, 2010; Sellers, 1997).

Although the research cited above has rather exhaustively explored the aggregate patterns of pork distribution, the underlying mechanics of the distributional process have been treated in a rather nebulous fashion. That is to say, the empirical patterns reveal that funds are channeled to specific members, but the question of who is responsible for the division has been left largely unspecified. For instance, Lazarus (2009) advances the argument that "majority party leaders are able to protect the projects going to their party's vulnerable members" (p. 1050). Similarly, Crespin and Finocchiaro (2008) provide evidence that majority party senators receive a disproportionate share of earmarks relative to the minority, whereas Shepsle et al. (2009) demonstrate a cyclical effect in appropriations earmarks corresponding with the staggered nature of Senate elections. To date, however, a clear exposition of who is responsible for the allocation decisions that we observe has been lacking. Therefore, we believe it is critically important to open this black box by highlighting some important aspects of the appropriations process in the House and, thereby, offering a more precise theoretical account of earmarking in Congress.

We begin with the observation that the universe of earmarks is not the most appropriate starting point for study. Rather, as Fenno (1966) observed, "the tasks of the Appropriations Committee are accomplished by its subcommittees" (p. 134). Although the committee may no longer stand as the guardian of the treasury, subcommittee autonomy in regard to earmarks remains the norm for House Appropriations, and subcommittees often have their own unique cultures and standard operating procedures. The 12 subcommittee chairs of each chamber, known as the cardinals because of their significant presence in the system, exert tremendous influence over the appropriations process, as do their ranking minority counterparts (Savage, 1991). The independence of the subcommittees also produces a level of influence for rankand-file members of the subcommittee (Fenno, 1966).

These aspects of subcommittee politics were reinforced in interviews we conducted with legislative staff. Describing earmark practices, one House staffer told us that each subcommittee

is its own entity and operates as such. They often require different information when making a request (i.e., some require a line item budget for the project [while] others do not) and they all have some variation in procedures for submitting a request (some require paper and electronic submissions while others are all electronic). ${ }^{2}$ 
The staffer went on to say that

what's important is the understanding and agreement between the ranking member and the [subcommittee] chair. And in general, that understanding includes the reality that ranking members control minority projects and chairs control majority projects. In fact, as a staffer, I assume this as fact. ${ }^{3}$

We also spoke with a former staffer for the majority leadership in the 111th Congress (2009-2010). He said, in addition, that "[then-Chairman] Obey, for the most part, stays out of the specific programs, decisions, etc., of the subcommittees" and that it is the cardinals who "manage the bills on the floor"- to such an extent that "subcommittees would sometimes provide their own vote recommendations on the floor." All of this underscores the independence of the House Appropriations subcommittees, as well as their leaders (including ranking members), in steering the flow of earmarks to the rank and the file.

Although some studies have accounted for the fact that cardinals should do better (see, for example, Lazarus, 2010), the linkage is rarely, if ever, made to the specific subcommittee of interest. ${ }^{5}$ Our argument is that, if subcommittees are the locus of decision making, then it is subcommittee chairs and their minority party counterparts (the ranking members) as well as, to a somewhat lesser extent, ordinary subcommittee members who should secure the most pork. One might think of this as the supply side of pork, because the subcommittee members - and particularly the cardinals and ranking members - are the ones who control the flow of pork.

We can draw multiple inferences about the earmarking process from the competing theories of legislative organization and previous research, as well as our theoretical perspective regarding the importance of subcommittee politics. Of course, the expectations, just like the theories, are not mutually exclusive (Hurwitz, Moiles, \& Rohde, 2001). However, we can determine whether the weight of the evidence points one way or the other. The distributive politics model predicts a committee-dominated process where committee members receive a greater share of the earmarks while not completely excluding nonmembers from the distribution. Similarly, we can draw several predictions from the partisan model. And finally, our theoretical understanding of the subcommittee process leads to a specific approach to examining their influence.

More specifically, distributive theories of legislative politics suggest the following hypotheses governing the distribution of pork in the House:

Hypothesis 1: Institutional considerations such as committee/subcommittee membership and leadership status will significantly drive the amount of pork received. 
Evidence in support of Hypothesis 1 will show that the most basic assumptions of the distributive theories are correct. That is, committees can guard their legislative outputs from unraveling on the floor.

Hypothesis 2: Nearly all members should receive at least some pork from some subcommittees, reflecting the prevalence of logrolling and the strategic importance of cultivating varied alliances.

Evidence in support of Hypothesis 2 will provide support for the more universalistic derivatives of the distributive theories best captured by Shepsle and Weingast (1981).

By contrast, partisan theories of legislative politics suggest that individual members and their characteristics are less central determinants. Instead, pork awards should be targeted so as to help the majority retain its control of the chamber. To wit

Hypothesis 3: A member of the majority party of the House will receive more pork on average, representing part of an overall strategy to re-elect their members and thereby retain majority status.

Hypothesis 4: A member of the majority party who occupies a marginal district will be granted more pork to protect the majority party's control of the chamber.

Evidence in support of Hypotheses 3 and 4 will provide support for the idea that parties can bias outcomes toward the majority party median and use the legislative process to make their members better off. These last two hypotheses assume that representatives equate more pork with increased chances of electoral success. In the next section of the article, we discuss in greater detail some of the empirical regularities of the subcommittee process, and then turn to a discussion of our data. The analysis that follows will explore these questions both descriptively and with the use of regression analyses.

\section{Data and Research Design}

As our expert interviews revealed in detail, the process of compiling the package of earmarks to be included in appropriations legislation occurs well before a bill reaches the floor of the House or Senate; in addition, important differences exist across the Appropriations subcommittees in the amount of pork distributed and the factors driving distribution (Crespin \& Finocchiaro, 2008; Shepsle et al., 2009). Thus, the picture of earmarks that emerges in the 
aggregate - for instance, 10,160 projects totaling US\$19.6 billion in 2009masks a tremendous amount of underlying variation among the 12 House and 12 Senate Appropriations subcommittees and the bills that they assemble. ${ }^{6}$ The production of the 12 appropriation bills is actually a complicated milieu of requests accumulated from members for specific projects in their states and districts, interactions with and among full and subcommittee staff and members, and eventual legislative vehicles that sometimes stand on their own while at other times end up being rolled into an omnibus measure (Crespin, Finocchiaro, \& Wanless, 2009).

Given the centrality of subcommittee-level decision making, our empirical approach examines pork allocation at the subcommittee level separately by party and also incorporates the direct effect of a member's status as a cardinal on that subcommittee. We adopt this disaggregated approach because it is our belief that it more clearly follows the data-generating process and to ignore it would omit important nuance in this aspect of distributive politics. If staff directly involved with the process believe this is how the system operates, we should at least initialize our study of it with this in mind. For this reason, we will drill down below the full committee and test our hypotheses about earmark allotments at subcommittee level.

The data analyzed in this study comprise earmarks fiscal years 2008-2009. The main dependent variable measures the earmarked dollars obtained by each legislator as reflected in the final conference reports for 10 of the 12 appropriations bills for both fiscal years. ${ }^{7}$ The 110th House was the first to be subject to rules requiring committee disclosure of the legislator requesting each earmark, thereby allowing us to more directly assess the degree to which individual members of Congress succeeded in obtaining earmarks. ${ }^{8}$ One drawback to the limited timeframe for our data analysis is the absence of variation in majority party control. As such, we need to be cautious in not generalizing beyond our period of study. To handle earmarks that were requested by more than one member of Congress, we divided the dollar amount of each earmark by the number of legislators that requested it and allocated that proportion of the earmark to each legislator. Ultimately we generated 11 variables at the member level: one for each of the 10 Appropriations subcommittees indicating the amount of earmark money received, and an additional variable indicating the total amount of pork received by each representative across the pool of subcommittees. In our regressions, we use the natural logarithm of these dollar figures for our dependent variable due to the rightward skew of the distribution. ${ }^{9}$

At this juncture, a few words are in order with respect to our decisions to (a) analyze earmarks and (b) employ dollar values as opposed to project counts. An attractive feature of earmarks as a measure of "pork" is that they 
are relatively narrow in their definition and are under the purview of members of Congress to a much greater extent than, for instance, the sorts of programs identified by the Federal Assistance Award Data System (FAADS), which has been the vehicle for analysis in much of the research on distributive politics (see, for example, Berry, Burden, \& Howell, 2010; Stein \& Bickers, 1995). In addition, earmarks are less susceptible to the analytical problems associated with endogeneity that are posed by other measures (such as FAADS), because efforts to obtain earmarks are limited to a short window of time and members are capped in terms of what a legislator can hope to obtain. ${ }^{10}$ Thus, it is not likely the case that added effort on the part of vulnerable members will produce significantly more earmarks - as such, concerns about a causal arrow that runs in both directions between earmarks and vulnerability are minimized. On the second point, we choose to employ a dependent variable based on the dollar value of earmarks as opposed to the number of projects for a few reasons. First, using a raw count limits our ability to distinguish among drastically variant awards because it treats a US $\$ 100,000$ earmark the same as a US\$1,000,000 earmark. Second, because the number of earmarks that members may request is limited, a count is censored in a way that the dollar value of earmarks is not. Finally, our theory is more concerned with how much members receive in comparison with whether they receive something at all.

To construct our independent variables, we used the Congressional Directory for the 110th Congress to identify the chair and ranking member of each subcommittee of the House Appropriations Committee and to identify every representative who served on the Appropriations Committee. ${ }^{11}$ Dichotomous variables in our dataset indicate whether the member was a cardinal or ranking member of the full Appropriations Committee, a cardinal or ranking member of a subcommittee, a member of the Appropriations Committee (or subcommittee where appropriate), and a member of the majority Democratic Party. Prior research has suggested that party leaders might also be expected to reap some rewards from their privileged institutional position, as well as seniority in the institution (see, for example, Lazarus, 2009). As such, we control for both of these with variables that code for leadership (Speaker and Majority Leader for the Democrats and Minority Leader and Minority Whip for the Republicans) and seniority, defined as the number of terms served as reported by CQ's Politics in America (Angle \& Koszczuk, 2007). Finally, we included a variable identifying whether a member's prior election was competitive. We ultimately settled on a dichotomous variable (Marginal District) coded one if the member received less than $60 \%$ of the vote in the previous election. ${ }^{12}$ We believe that a dichotomous as opposed to a continuous variable is preferable because the traditional measure of 
competitiveness using previous vote share assumes a consistent linear effect from the most competitive to the least competitive district. Once members earn at least $60 \%$ of the vote, it is reasonable to assume that they are no longer vulnerable. ${ }^{13}$

In addition to the preceding variables that correspond to the factors of interest from the theoretical arguments presented earlier, we also account for district demand. As Frisch and Kelly (2011) note, earmarks are frequently responses to local conditions. Many members encourage constituents or organizations to request earmarks through a routinized process that includes filling out a form that is often posted on the member's webpage. In this view, legislators channel district demands as they determine which requests to pursue formally in the earmark process. A story in the Washington Post is illustrative. Alaska Rep. Don Young "has equated earmarks with serving his constituents, telling his local paper that as long as constituents 'continue to request federal funding for their projects of interest, then I will continue to do my best to accommodate them"' (Leonnig, 2010).${ }^{14}$ Finally, because our data span two fiscal years, we include a dichotomous variable for 2008 to account for any temporal effect.

With this in mind, our examination of earmarks at the subcommittee level directly accounts for district demand following Adler's (2002) committeeby-committee specification of district characteristics, which we have extended through the 2000s wave of redistricting. Because Adler's data extend only through the 1990s redistricting, we updated most of the measures to the 2007-2008 districts and mapped the old jurisdictions to the new ones (jurisdictions were shifted, and subcommittees renamed, multiple times in the 2000s). Appendix A of the Supporting Information (https://thedata.harvard.edu/dvn/dv/finocchi) presents a brief overview of the variables that we were able to reconstruct and their linkage to the various subcommittees. These measures were then used to create a "demand" variable for each subcommittee. To create the subcommittee measures of demand, we again followed Adler, standardizing each of the individual component measures (i.e., each component was rescaled to have a mean of zero and a standard deviation of one) and then summing across each of the individual measures. The "total" demand variable for the initial results presented below is the summation of each of the subcommittee variables.

\section{Results}

In the tables and figures below, we provide some descriptive statistics for our data. We then turn to a series of ordinary least squares (OLS) regression results demonstrating that although there are some similarities across subcommittees, 


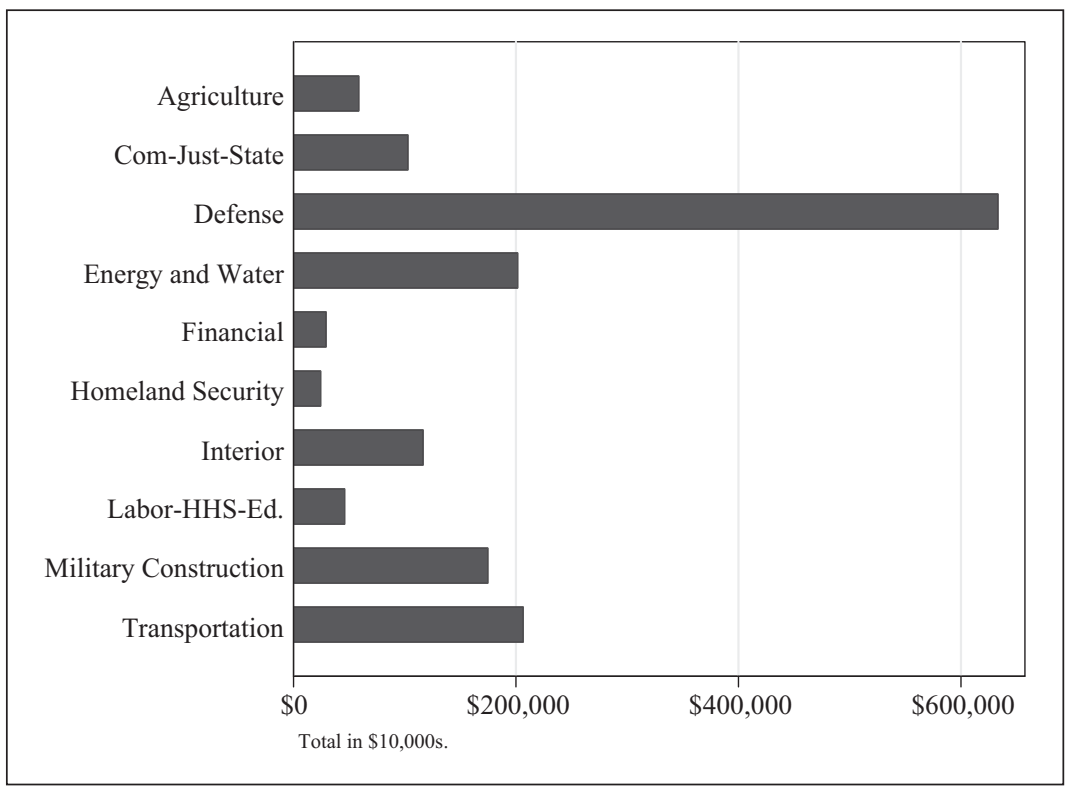

Figure I. Total earmark dollars by subcommittee.

there are important differences as well. In addition, our goal is to consider which of the theories of legislative organization are most clearly borne out in the data.

Figure 1 provides an accounting of earmarks for 10 of the 12 House spending bills. Consistent with previous research (Crespin et al., 2009), there is substantial variation across subcommittees. In total, these bills contained just less than US\$16 billion worth of earmarks. Similar to previous years, the Defense bill contained the most pork - more than US\$6 billion total, which represented roughly $40 \%$ of all earmarks for the two fiscal years. The Energy and Water, Military Construction, and Transportation bills were the next largest tier, with more than $10 \%$ of earmark dollars each. The other six bills together contained just less than a quarter of the total.

Figure 2 plots the distribution in the number of Appropriations subcommittees from which members received earmarks. Although the modal number of subcommittees is 7 (of the 10 we consider in our analysis), in just more than 50 cases from the two fiscal years analyzed, members received no earmarks. ${ }^{15}$ At the other extreme, in 31 instances members received earmarks from every subcommittee. This variation underscores the importance of considering subcommittee-level differences in the factors driving the earmark 


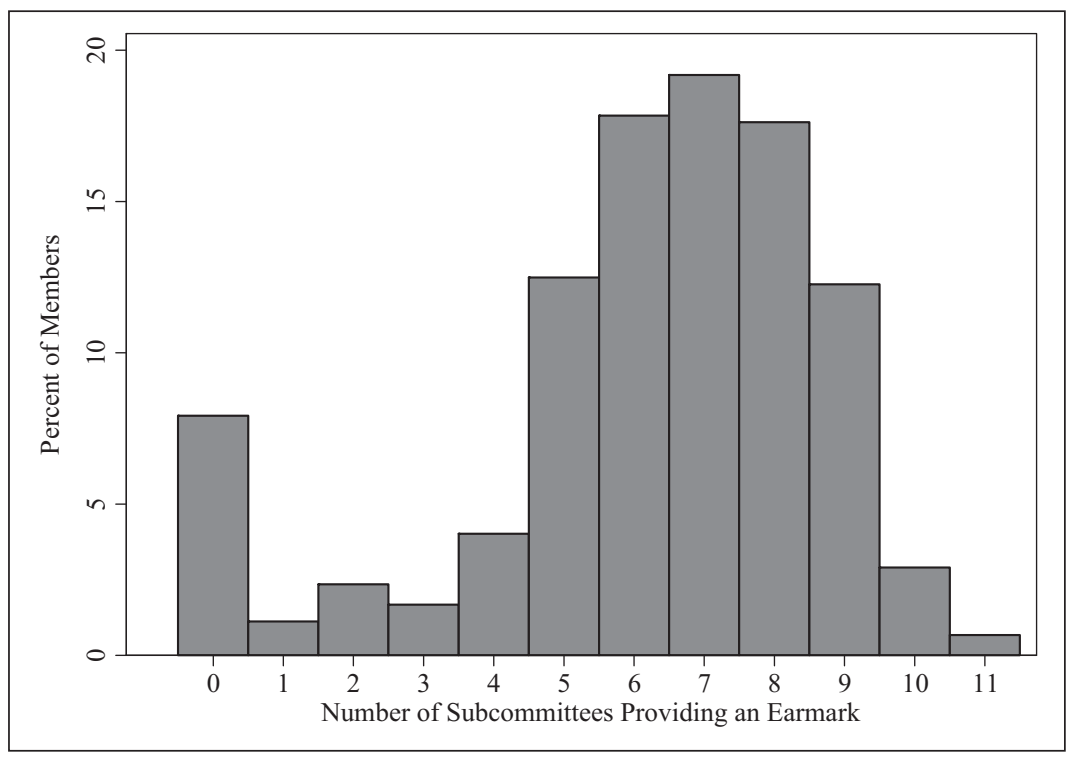

Figure 2. Variation in member receipt of earmarks by subcommittee.

process in the House. It also provides initial support for Hypothesis 2 in light of the fact that most members receive at least some earmarks.

In Figure 3, we show the percent of earmark dollars for each subcommittee that went to members serving on the full House Appropriations Committee and the relevant subcommittees. If the chairs and ranking members of the Appropriations subcommittees distributed earmarks in an equal fashion, we would expect each House member to receive 1/435th of the total earmark dollars. This would translate to about $15 \%$ of earmarks going to the 66 members of the House Appropriations Committee and roughly 3\% to each subcommittee. We see, however, that members of the Appropriations Committee obtained nearly $35 \%$ of all earmark dollars, more than twice what we would expect given a proportional allocation. There is a similar, if not starker, pattern for subcommittee members. In terms of the different subcommittees, members with a seat at the appropriations table got more than half of the earmark dollars for the Homeland Security subcommittee and just less than half for the Agriculture subcommittee. For the subcommittee with the most earmarks to go around (Defense), members of the Appropriations Committee took nearly $40 \%$ of the total, just less than US $\$ 2.5$ billion. The only committee where appropriators received less than expected is Financial Services where 


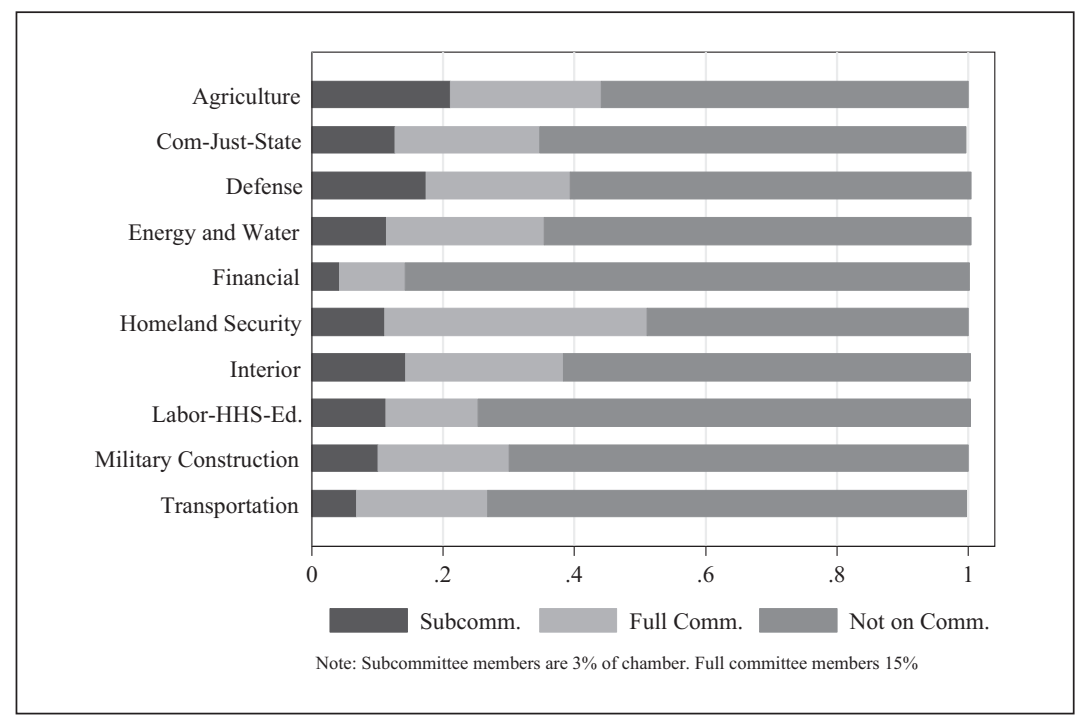

Figure 3. Percent of earmark dollars by committee membership status.

they garnered only $14 \% .{ }^{16}$ Taken as a whole, then, this figure provides evidence that committees dominate the earmark process consistent with a distributive perspective on legislative organization and supports Hypothesis 1.

Figure 4 breaks down the amount of earmark dollars by party and subcommittee and provides evidence in favor of Hypothesis 3. As expected, the majority party Democrats, despite controlling only $53.6 \%$ of the seats in the 110th House, took just more than $60 \%$ of the earmark dollars, leaving the rest for the minority Republicans. Compared with our other figures, there is less variation across subcommittees, suggesting an accepted norm of sharing earmarks at this ratio for each subcommittee. As we noted earlier, we need to be cautious in generalizing here because our data do not include a change in majority control. Nevertheless, the majority party advantage is consistent with remarks by members of Congress and previous work both in the House (Balla et al., 2002) and the Senate (Crespin \& Finocchiaro, 2008). By giving a respectable share of earmarks to the minority party, Balla et al. (2002) argue that the majority party avoids the public backlash that might arise from unilaterally spending money on local rather than national needs. Moreover, the results support the argument made by scholars that the legislative process brings added benefits to majority party members (see, for example, Cox \& Magar, 1999). 


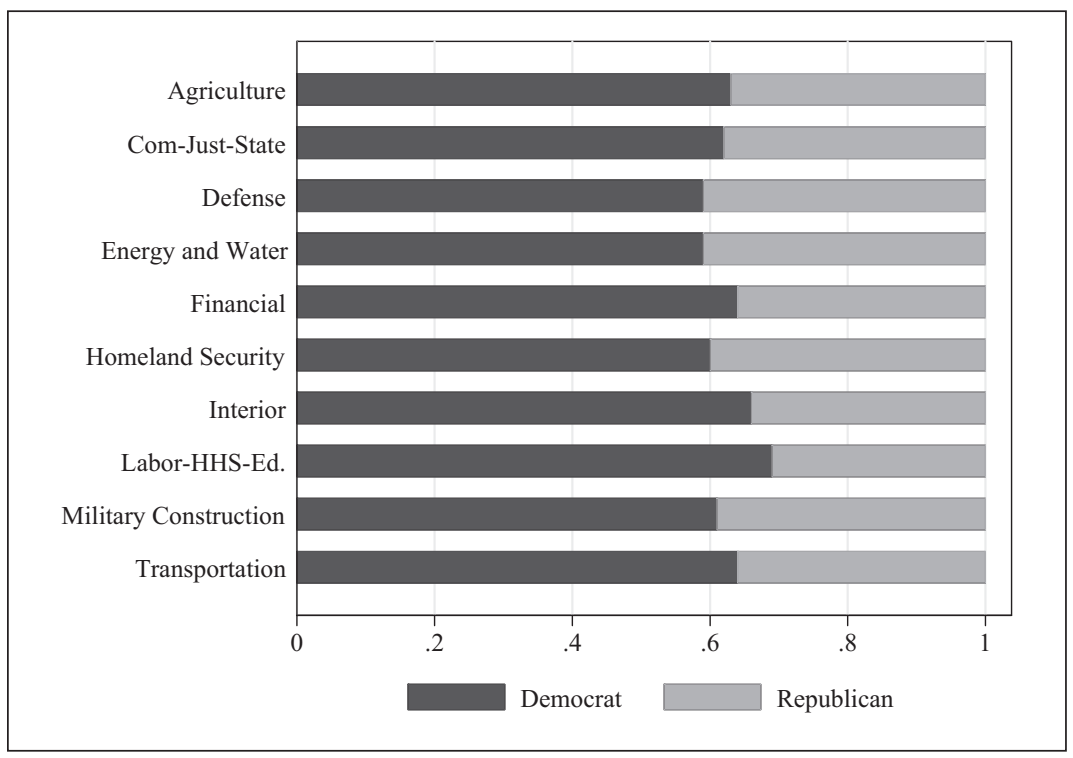

Figure 4. Percent of earmark dollars by party and subcommittee.

Finally, in Figure 5 we report the average amount of earmark dollars at the member level, conditional on the competitiveness of the previous election. Democrats and Republicans are plotted separately. Here, and in the regression analysis that follows, we call a district marginal if a member received less than $60 \%$ of the vote. If earmarks represent a way for members to increase their chances for reelection, we would expect those from more competitive districts to receive more earmark dollars, on average, than their colleagues. Contrary to this perceived wisdom (and Hypothesis 4), this figure and our regression analyses at the subcommittee level fail to show that members from marginal districts consistently received more earmark dollars compared with safe members. For example, Figure 5 indicates that marginal Republican members earned more from one committee, Labor-Health and Human Services-Ed. (hereafter Labor-HHS-Ed.), but less from two others (Agriculture and Defense). Democrats from marginal districts received significantly more in Military Construction earmarks, yet they found themselves with less from the Commerce-Justice-State bill (hereafter CJS). There are two possible reasons why we might uncover this result. First, prior research has found Republicans tend not to benefit from this type of federal spending so the largely null result here should not be too surprising (Alvarez \& Saving, 


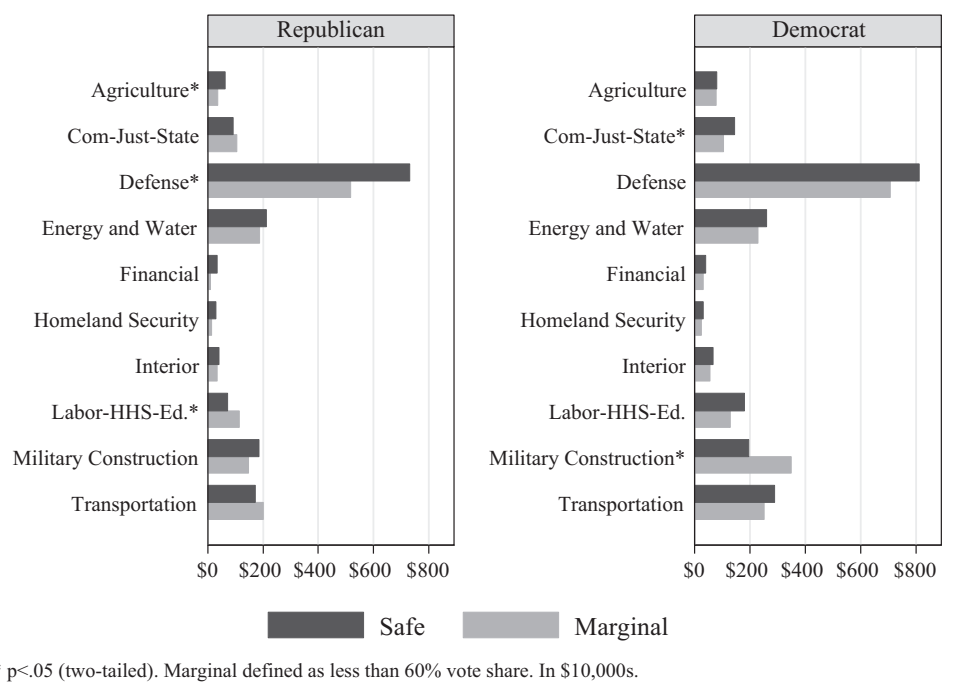

Figure 5. Average value of earmarks by district competitiveness. $*_{p}<.05$ (two-tailed).

1997; Crespin \& Finocchiaro, 2013; Lazarus \& Reilly, 2010; Sellers, 1997). Second, although the majority leadership has a strong incentive to maintain its majority and the power that goes along with it, cardinals and ranking members tend to be powerful independent of majority status. This means that they may have other goals and choose to hand out earmarks in ways that are not always consistent with leadership goals. This implies a tension between the two foci of power within the chamber. Although the recent House earmark ban helps to project an image of fiscal responsibility, it has also stripped power away from the Appropriations Committee and centralized it within the party leadership. Of course, one should be wary of drawing too much from this figure because it does not account for any potentially confounding factors.

Nonetheless, the descriptive statistics highlighted in these figures provide preliminary evidence in favor of distributive theories that committee members dominate the earmark process by taking a greater share of earmark dollars. We do not see that members from marginal districts are consistently receiving extra earmarks to bolster their reelection chances. Together, these results suggest that institutional positions such as serving on the Appropriations Committee or being in the majority party trump electoral concerns. To 
Table I. OLS Regression of Earmark Receipts-Total and by Party.

\begin{tabular}{|c|c|c|c|}
\hline Variables & All earmarks & Democratic & Republican \\
\hline \multirow[t]{2}{*}{ Chair } & $0.697 *$ & $0.697^{*}$ & - \\
\hline & $(0.229)$ & $(0.223)$ & \\
\hline \multirow[t]{2}{*}{ Ranking member } & $2.287^{*}$ & - & $2.155^{*}$ \\
\hline & $(0.094)$ & & $(0.136)$ \\
\hline \multirow[t]{2}{*}{ Cardinal } & $1.122 *$ & $1.116^{*}$ & - \\
\hline & $(0.228)$ & $(0.219)$ & \\
\hline \multirow[t]{2}{*}{ Sub. ranking member } & $1.603^{*}$ & - & $1.616^{*}$ \\
\hline & $(0.180)$ & & $(0.173)$ \\
\hline \multirow[t]{2}{*}{ Appropriations member } & $0.925 *$ & $0.870^{*}$ & $1.053^{*}$ \\
\hline & $(0.090)$ & $(0.119)$ & $(0.123)$ \\
\hline \multirow[t]{2}{*}{ Leadership } & $1.360 *$ & $1.319 *$ & I.498* \\
\hline & $(0.223)$ & $(0.3 \mid I)$ & $(0.076)$ \\
\hline \multirow[t]{2}{*}{ Seniority } & $0.023 *$ & $0.027 *$ & 0.025 \\
\hline & $(0.009)$ & $(0.011)$ & $(0.014)$ \\
\hline \multirow[t]{2}{*}{ Marginal district } & $0.230 *$ & $0.387^{*}$ & 0.094 \\
\hline & $(0.073)$ & $(0.088)$ & $(0.106)$ \\
\hline \multirow[t]{2}{*}{ Demand } & 0.003 & -0.004 & $0.012^{*}$ \\
\hline & $(0.004)$ & $(0.006)$ & $(0.004)$ \\
\hline \multirow[t]{2}{*}{ Democrat } & $0.333^{*}$ & - & - \\
\hline & $(0.068)$ & & \\
\hline \multirow[t]{2}{*}{ Year (2008) } & $0.119 *$ & 0.067 & $0.177 *$ \\
\hline & $(0.037)$ & $(0.036)$ & $(0.069)$ \\
\hline \multirow[t]{2}{*}{ Constant } & I5.720* & I6.046* & I5.739* \\
\hline & $(0.086)$ & $(0.092)$ & $(0.1 \mid 5)$ \\
\hline$n$ & 818 & 465 & 353 \\
\hline$R^{2}$ & .296 & .268 & .319 \\
\hline
\end{tabular}

Note. Standard errors clustered on member. Dependent variable is the log of total earmarks in US\$10,000s. OLS = ordinary least squares.

$*_{p}<.05$ (two-tailed).

examine these factors together, we next use OLS regression to control for various factors that might also be influencing the outcome.

In Table 1, we examine pooled earmarks and test for the influence of the variables described above. In Tables 2 and 3, we investigate whether the results are consistent when we examine the earmarks for each of the subcommittees across the two parties. Because our understanding of the earmark process suggests that the cardinals and ranking members run the subcommittees with a degree of autonomy from external actors, the second set of results 


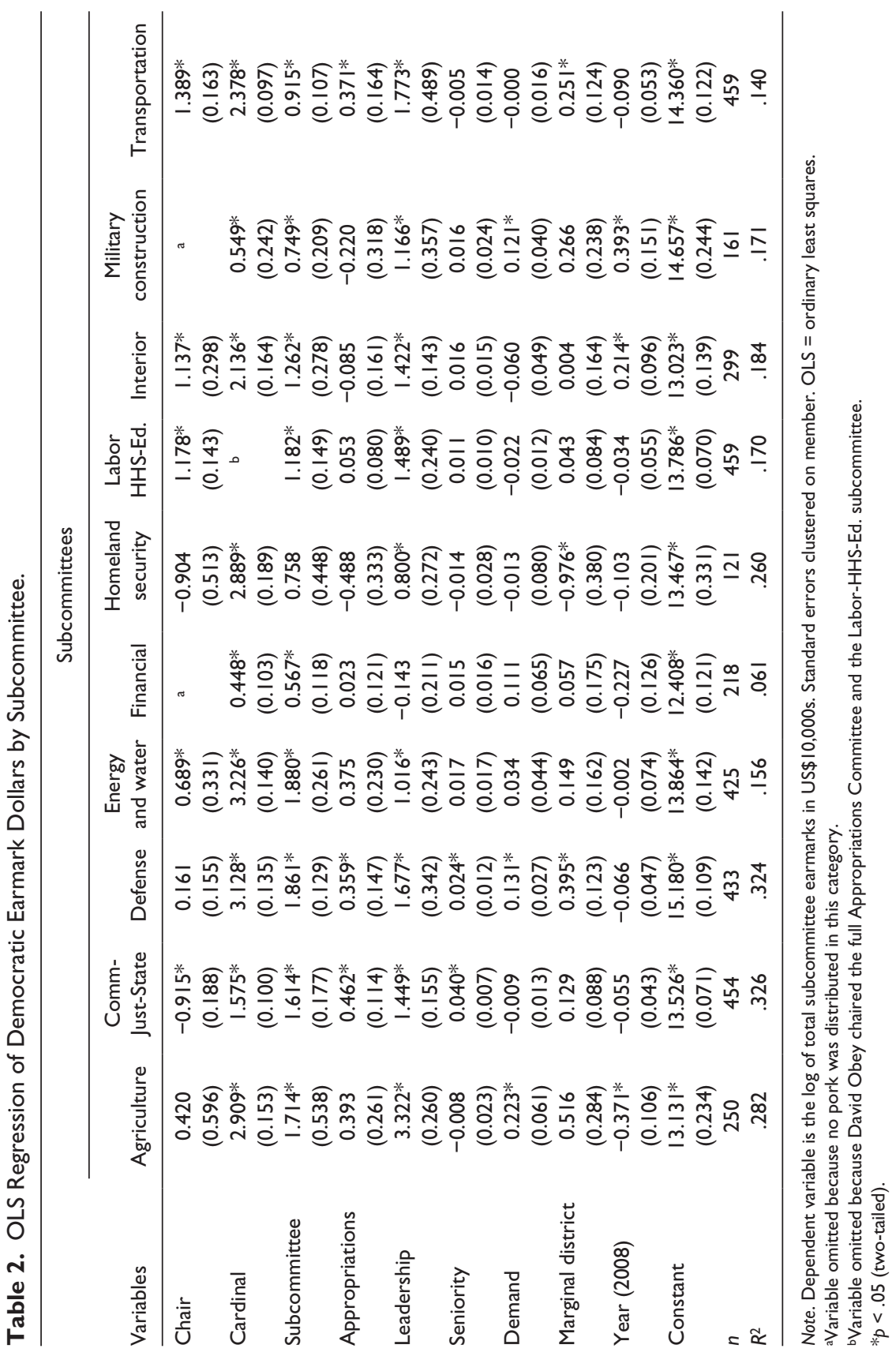




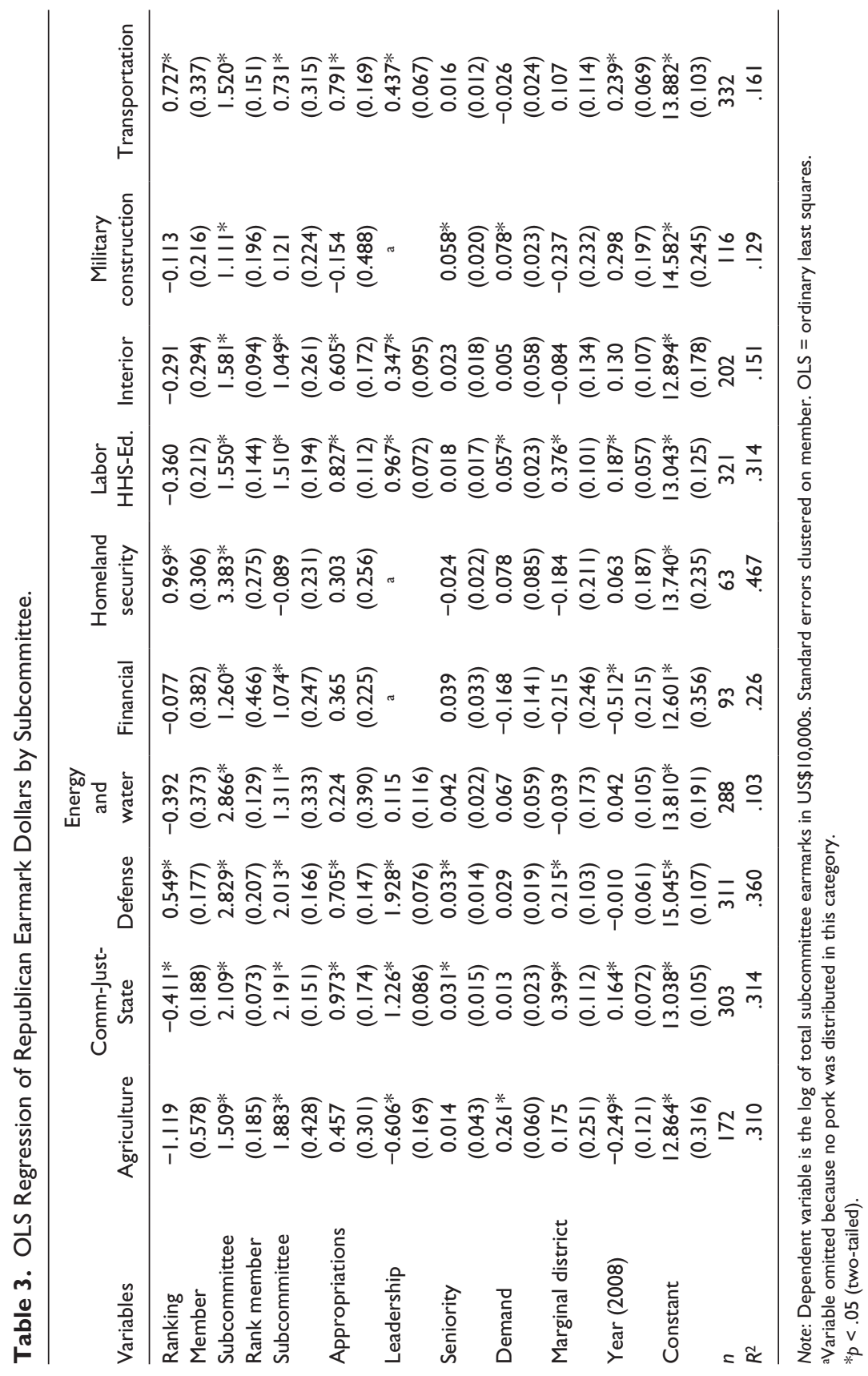


should more accurately reflect actual variation across different members or districts, especially when compared with previous research. For each set of regressions, the unit of analysis is the member-fiscal year, so members can appear in the dataset twice if they received earmarks in both fiscal years. We cluster the standard errors on individual members to control for possible dependence.

For the regressions pooling all earmarks in Table 1, the results are largely as we expected. Because the dependent variable is the natural log of pork dollars, we exponentiate the coefficient to determine the percentage change in earmark dollars for a one-unit change in a particular independent variable. This means, for instance, that a member with one additional term of seniority receives $2.3 \%$ more in earmark funds. David Obey, the chair of the full Appropriations Committee, took home 101\% more as the chair and then an additional $207 \%$ due to his status as a cardinal (in this case, of LaborHHS-Ed). ${ }^{17}$ The ranking member of the full committee, Jerry Lewis, was perhaps the biggest winner, taking $892 \%$ more than a rank-and-file member. The results also indicate significant returns for subcommittee ranking members $(402 \%)$, appropriators who are not cardinals or ranking members (152\%), and members in the chamber leadership (291\%).

In this pooled model, members from marginal districts earned more earmark dollars than members from less competitive districts. This result is somewhat surprising given the previous results from Figure 5, but it squares with conventional wisdom about electioneering and pork (Stein \& Bickers, 1995), as well as the findings of Lazarus (2009) and Engstrom and Vanberg (2010) with respect to earmarks specifically. However, the increase of just $26.1 \%$ is small compared with the coefficients on the institutional variables. Marginal district is a dichotomous variable in our model that indicates whether the member's previous vote share was less than $60 \%$. To explore the robustness of this measure, we employed two other cutoffs, at $55 \%$ and $65 \%$. These results are reported in Appendix B of the Supporting Information (https://thedata.harvard.edu/dvn/dv/finocchi). None of the key variables changed in sign or significance, and the coefficients as a whole were affected very little. Notably, the coefficient on marginal district barely changed at all. Returning to the main results, in terms of demand, we find that districts with more "need" for earmarks were no more likely to get them. Finally, as expected, Democrats obtained 40\% more earmark dollars compared with members of the minority party. This first look at the regression results underscores the significant impact of the institutional variables and comports with distributive theory. However, the significant coefficient on the party variable with the majority party taking more supports partisan theories, albeit with an effect that is small even compared with just serving on the Appropriations Committee. 
When we compare the results across parties, we find some similarities and some important differences. For example, members in the chamber leadership for both parties earned roughly the same increase in earmark dollars. This result should not be too much of a surprise as the committee has some incentive to adhere to requests from the leadership. Although we argue above that the committee operates with a great deal of autonomy from party leadership (Adler, 2000), the independence can be reined in as power is centralized away from the committees. In fact, we see the recent earmark ban as just such an example. It appears that the committee is not as desirable as it was in the past with former members under ethics investigations and some arguing the committee is under assault on the Hill and from voters. ${ }^{18}$

We also continue to find evidence that the full committee chair and ranking member, cardinals and subcommittee ranking members, and ordinary appropriators all received increased earmarks compared with others. Yet, the percentages are not the same across the two parties, with Republican appropriators taking a somewhat higher percentage than their Democratic counterparts. This might reflect sorting as Republican high demanders make their way to the Appropriations Committee while there are more Democratic demanders without seats at the table. The results also indicate that added seniority aids Democrats but not Republicans in receiving more earmark funding.

Turning to electoral concerns, the results show that the Democrats allocated $47.4 \%$ more earmarks to members from marginal districts whereas the Republicans do not appear to have assisted vulnerable members in this way. Although we cannot tell if this is a Democratic effect or a majority party effect, it seems unlikely that the Democrats would change this pattern of earmark allocation if they were in the minority. Also, our interviews suggest that the party contingents on the Appropriations Committee allocate their share of earmark dollars independently of one another, so it is not likely the case that Democrats were preventing Republicans from using pork for electoral reasons. Finally, the demand variable is not significant in the Democratic model although it is for the Republicans.

In the next phase of our analyses, we deal more directly with the subcommittee-level focus of our theoretical argument. Because we believe that subcommittees are responsible for the data-generating process, and coefficients should therefore be estimated to reflect the conditions that prevail in each subcommittee, we estimate regressions for each subcommittee separately by party. The variables in each of the models are constructed similarly to those in the models for total earmarks with the exception of the Demand variable, which is now specific to the individual subcommittee, and the Appropriations variable, which indicates membership on the full committee but not the relevant subcommittee. 


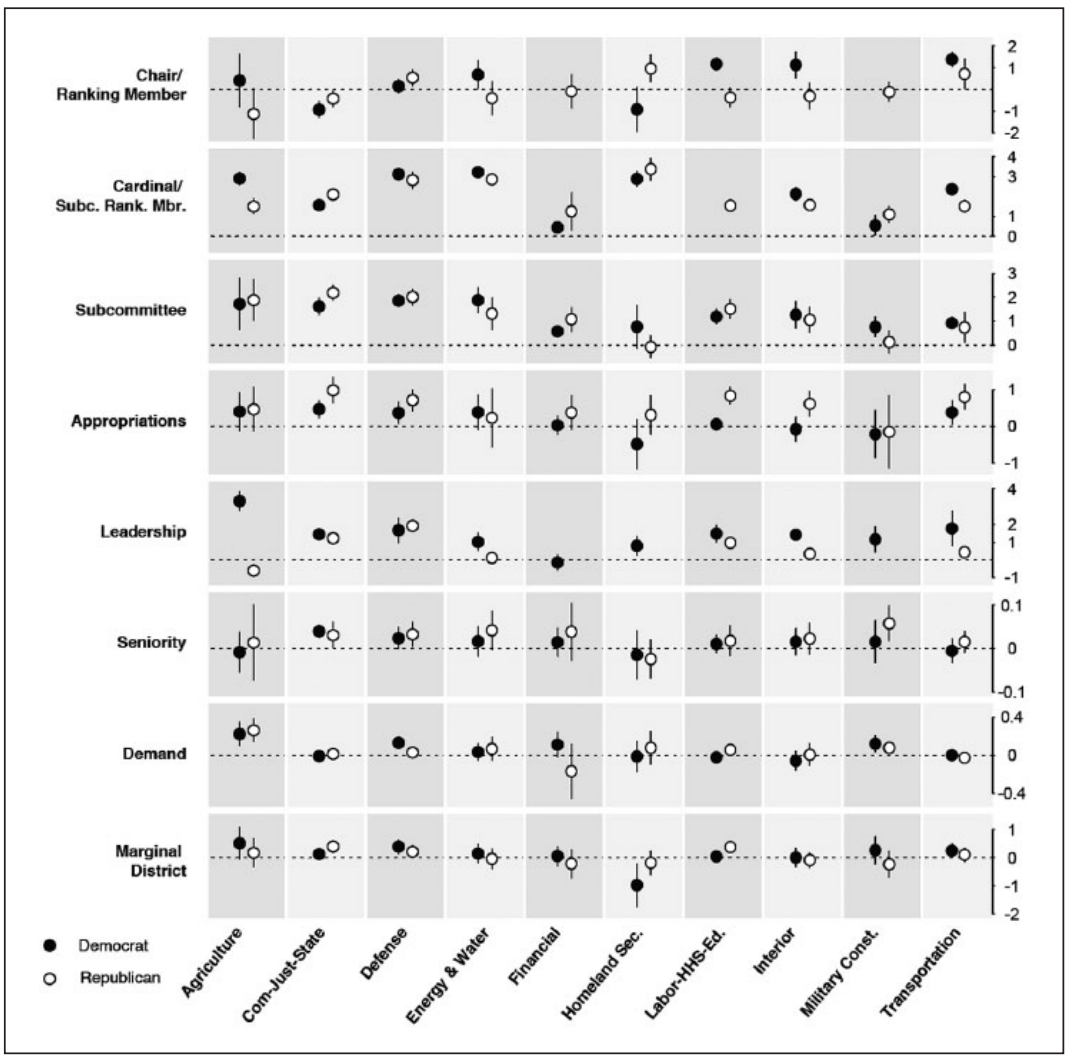

Figure 6. Summary of subcommittee OLS regression coefficients by party. Note. Circles indicate the coefficient estimates and vertical lines depict the $95 \%$ confidence intervals. OLS $=$ ordinary least squares.

To better compare the results across the 20 regressions, Figure 6 graphs the coefficients and $95 \%$ confidence intervals for each of the subcommittee estimates by party. To summarize the essence of our findings, we see that the key variables related to institutional standing-leadership and membership on the relevant subcommittee, holding a seat on Appropriations, and party leadership status - frequently produce a larger percentage of pork. Seniority occasionally is significant but the effect is not large. Interestingly, marginality more often than not fails to obtain statistical significance at conventional levels and when it does, the effect is muted compared with the key institutional variables. Demand is an important factor for the Agriculture and 
Military Construction subcommittees for both parties, as it is for Defense but only among Democrats. This finding is consistent with the long-standing view of these policy areas as populated with "high demanders." Yet demand appears to have made very little difference in terms of the dollar amount of earmarks secured for either Democrats or Republicans for the rest of the subcommittees.

Tables 2 and 3 present the detailed results for each of the models and allow us to go into more detail on the substantive impact of institutional versus other variables. Looking across the rows in Table 2 for Democrats, we find that David Obey secured an extra share of earmark dollars from Energy and Water, Labor-HHS-Education, Interior, and Transportation while collecting significantly fewer earmarks from CJS. The results also indicate that cardinals reaped extra earmark dollars from each of the subcommittees they chaired. John Murtha, dubbed the "King of Pork" by the New York Times (The Pork King Keeps His Crown, 2008), fared quite well, taking 2,178\% more dollars in Defense earmarks from the subcommittee with the most earmark dollars. Energy and Water Cardinal Pete Visclosky took home a slightly larger share, at 2,418\%, although it came from a smaller pool of money.

As expected, members who served on the individual subcommittees obtained more earmarks than those not on the subcommittees in all but one case, Homeland Security. Democratic members of the full committee earned more earmark dollars in just three cases-CJS, Defense, and Transportation. The results also indicate that the leadership took an additional helping of earmark dollars from nine of the subcommittees. Finally, the demand variable is significant in the expected direction for only three subcommittees. The lack of more consistently significant relationships may be a function of the fact that constituency demand is, at least to some degree, encapsulated in subcommittee membership because high demanders are more likely to find themselves on the relevant committees than those who are uninterested (Adler, 2000; Adler \& Lapinski, 1997).

One result that is different in contrast to the pooled model involves the marginal district variable. Here we see that among Democrats, the electoral concerns of members exhibited a positive effect on the procurement of pork on just the Defense and Transportation subcommittees, two of the classic constituency-oriented subcommittees. Moreover, electoral marginality is negative and significant for the Homeland Security subcommittee, suggesting that the impact of this variable is severely limited in its scope. As in the pooled model, we examined the robustness of these results using two different cutoffs to determine when a district is considered to be marginal. These resulting coefficients for the marginal district variable for all 20 models are shown in Table B2 of the Supporting Information (https://thedata.harvard. 
$\mathrm{edu} / \mathrm{dvn} / \mathrm{dv} /$ finocchi). These robustness tests actually reduce the number of cases where the marginal district variable is significant - it reaches the conventional level of significance in just 3 of the 20 models if a $55 \%$ vote share cutoff is used, and only 2 of the 20 models if a $65 \%$ vote share cutoff is used.

We turn next to the results for the Republican Party, which appear in Table 3. Here, we see that, similar to his majority party counterpart, full committee ranking member Jerry Lewis took extra earmarks from a few subcommittees-Defense, Homeland Security, and Transportation — but less from CJS. Subcommittee ranking members also received extra earmarks from their respective panels in every instance, whereas representatives serving on the individual subcommittees obtained more earmark dollars in 8 of 10 cases. We also see here that members of the full committee obtained extra earmarks from half of the subcommittees. When they took pork, leadership got more at the subcommittee level with the exception of Agriculture and Energy and Water. For the three instances in which members in the leadership procured no earmarks, we believe they simply did not ask because it seems unlikely that the ranking members of Financial Services, Homeland Security, or Military Construction would deny the party leaders earmark requests. We also find that more senior members obtained additional earmarks from the CJS, Defense, and Military Construction subcommittees.

Although the marginality of Republican members' districts did not exhibit a statistically significant effect in the pooled model, our investigation at the subcommittee level reveals that on the CJS, Defense, and Labor-HHS panels, vulnerable members received a disproportionate share of pork. Yet again the effects are small compared with serving on the subcommittees. In just three instances-Agriculture, Labor-HHS, and Military Construction - the demand variable is positive and significant.

Taken together, these regression results reveal that the most consistent effects reside with the institutional variables. Members with a significant hand in the appropriations process in Congress-from the chair of the full committee to subcommittee cardinals and ranking members down to rankand-file appropriators - are the ones who dominate the process. In addition, the subcommittees do not operate in an identical fashion, as we observe variation in the size of significant coefficients and a lack of significance in other cases. In light of our expectation that the process is one that plays out at the subcommittee level, these findings should not be surprising, yet it stands in contrast to the approach taken in many studies of earmarks. We also show differences between Democrats and Republicans, again to be expected because the two parties for the most part operate independently when dispensing earmarks to their members. 
These results largely support a distributive politics model of the earmarking process. The descriptives verify that nearly all members receive some pork (supporting Hypothesis 2), with the few holdouts likely comprising representatives facing unusual electoral circumstances and/or articulating outspoken positions against the pork barrel. Institutional factors related to committee and subcommittee duties are critical to understanding how pork is distributed and our evidence supports Hypothesis 1. Nonetheless, there is some support for the idea that partisan concerns play a role in determining earmark awards. The majority party tends to receive a share of earmarks that is higher than its seat share would predict, in line with Hypothesis 3 . However, only a few subcommittees appear to be sensitive to the needs of party members in marginal districts, thus there is much less evidence in favor of Hypothesis 4. Of course, we need to once again acknowledge our limited data timeframe and the lack of variation in majority status.

\section{Discussion}

In this article, we have assessed earmark allocation in the House of Representatives by parsing the effects of various factors linked to leading theories of legislative politics. We argue and demonstrate that members who control the supply of earmarks - that is, the Appropriations Committee chair and ranking member, subcommittee cardinals and ranking members, and rank-and-file members of the full committee or subcommittee-usually receive a larger share of the earmark pool. In addition, we highlight the significant variation across the parties and subcommittees in the rate at which members receive earmarks.

We then go one step further and show that although there are many similarities, Democrats and Republicans do not always allocate earmarks in identical ways. Nor do subcommittees operate identically, as Fenno (1966) pointed out a generation ago. Rather, our separate analyses for each subcommittee demonstrate that the earmark process is not as neat and tidy as pooled models indicate. For example, we fail to find consistent evidence at the subcommittee level that members of either party who are electorally vulnerable receive extra money for projects in their districts. This suggests a more nuanced relationship between marginality and earmarks that does not become apparent when examined with pooled data. In some ways, the results from the subcommittee models are unsatisfying because they call into question some of the generalizations that we can draw from pooled models. However, our reading of journalistic accounts, observations of the appropriations process, and discussions with staff indicate that this level of analysis is appropriate for understanding the allocation of earmarks because it more closely resembles the actual data-generating process (Morton, 1999). 
As a whole, the results seem largely to support the distributive politics perspective of legislative organization because it is the institutional variables that have the largest influence and are quite consistent in their effect. In some ways, this should not be surprising because we are, after all, describing and modeling a process that the theories were designed to explain. Nonetheless, in recent years, scholars have tended to use earmarks and other aspects of distributive politics to try and test competing theories of legislative politics more broadly. We show here that the majority party does have an advantage in the system because the overall split favors those in the majority. Nonetheless this is only a small part of the story. We can make a similar point about the electoral-based story as it only provides limited traction. Yes, in certain cases and in certain subcommittees, members from electorally vulnerable districts get a bit more, but the advantage pales in comparison with that enjoyed even by rank-and-file appropriators. If the party leadership was concerned solely with helping members get reelected, we would expect to find a more pronounced effect, especially within the majority Democratic Party. Of course, given the limited data that are available, it is difficult to extrapolate beyond this single Congress, and if the impact of particular variables has changed over a broader period of time (e.g., the strength of parties), then our analysis cannot detect such changes.

Beyond the earmarks, this research tells us that the House is not a monolithic chamber where the Speaker and leadership control every aspect of legislation. Rather, there are (or were) a few pockets of independent power left in the chamber tied to the power of the purse. In the current age of budget tightening and limitations on earmarks, this power has declined and members may be less likely to pursue representative agendas that center around sending federal largesse back home. Although this means a transfer of power away from the Appropriations Committee and toward the leadership, it might also put more power in the hands of the executive who can control other aspects of federal spending (Berry et al., 2010).

Moving forward, when examining distributive politics in Congress, scholars need to be sensitive to both the underlying mechanisms and the level of analysis when aggregating data that are generated by a more atomistic process. This is true even though the House's Republican majority has effectively banned earmarks in spending bills since 2011. If we were to delve into non-earmark appropriations, for instance, it is very likely we would find parallel differences across parties and subcommittees. In the present world of heightened polarization, it seems doubtful that the House will return to a full-fledged model of subcommittee government any time soon, yet it still seems to be the case that subcommittees are an important component of one of the key constitutional functions that the Congress is charged to performexercising the power of the purse. 


\section{Declaration of Conflicting Interests}

The author(s) declared no potential conflicts of interest with respect to the research, authorship, and/or publication of this article.

\section{Funding}

The author(s) received no financial support for the research, authorship, and/or publication of this article.

\section{Notes}

1. We refer the reader to Cox and McCubbins (2005) for a more thorough review of the congressional organization literature. For criticism of partisan theories, see, for example, Krehbiel (1999), and for discussion of the interplay between positive and negative agenda control in partisan theories, see Finocchiaro and Rohde (2008).

2. The variation in practice between subcommittees is also evident in the observation of Shepsle, Van Houweling, Abrams, and Hanson (2009) that, although most panels insert the bulk of their earmarks at the subcommittee stage, Labor/HHS has a tradition of inserting earmarks at the conference committee stage.

3. Interview conducted via email December 19, 2009. The majority party staffer worked in the same office during times of both majority and minority status and now handles all appropriations requests for the office.

4. Interview conducted by telephone February 5, 2010.

5. Shepsle et al. (2009) note in their study of the Senate that they estimated but did not report models controlling for subcommittee status, stating in summary that "agenda setters receive substantially more appropriations in their chamber than others" (p. 356). They attribute this effect, at least in part, to the fact that such privileged positions are likely to be a "posttreatment" effect of the electoral cycle effect that they propose. That is, they believe vulnerable members in cycle are placed on relevant subcommittees or given cardinal status.

6. Source: Citizens Against Government Waste: http://cagw.org/content/pigbook-2009 (last accessed Jan. 31, 2014).

7. We do not include State/Foreign Operations or the Legislative Branch bills because they saw very little in the way of earmarks. Rather than use existing preprocessed data from Citizens Against Government Waste or Taxpayers for Common Sense, we collected the data ourselves directly from the relevant sections of the appropriations bills and conference reports. The data were collected from the conference reports for each appropriations bill. For fiscal year 2009, two omnibus bills were passed (H.R. 2638 and H.R. 1105) with earmarks that were listed by legislator in the conference reports, which are available at http:// www.gpo.gov/fdsys/pkg/CPRT-110HPRT44807/content-detail.html and http:// www.gpo.gov/fdsys/pkg/CPRT-111JPRT47494/content-detail.html. The conference report for the Consolidated Appropriations Act for fiscal year 2008 (H.R. 2764) can be found at http:/www.gpo.gov/fdsys/pkg/CPRT-110HPRT39564/ 
content-detail.html. Committee reports for stand-alone legislation, as well as a number of other details on the appropriations process, are available from the Library of Congress: http://thomas.loc.gov/home/approp/index.html. To compile our data, each earmark was copied directly from a list in the conference report and the text was then cleaned and earmarks assigned to legislators using a simple Python script. Collecting the data ourselves allows us to split multi-member earmarks between the legislators who receive them instead of giving each legislator full credit for these shared earmarks, as Taxpayers for Common Sense (TCS) does. Despite this decision, the correlation between our data for 2008 and TCS's single-member 2008 data is .90 .

8. For appropriations legislation spanning fiscal years 2008 and 2009 , nearly every measure was eventually passed as part of an omnibus appropriation (the only exceptions were the FY 2008 Defense Appropriations bill, which passed on its own, and the Labor-HHS-Education bill, which was vetoed by the President and later rolled into the consolidated measure). The 2008 legislation was also somewhat unique in that many of the earmarks, while subject to stricter rules about transparency, were not revealed until late in the appropriations cycle (Spruiell, 2007). Despite the delay in advancing the legislation and producing the list of earmarks, the omnibus measure still contained nearly 9,000 earmarks (Hulse, 2007; Williamson, 2007).

9. Because the natural logarithm of zero is undefined, this transformation eliminates members who did not receive any earmarks. This leaves us with the choice of either dropping these members or including them by coding them as receiving some small positive value such that the natural log of that value is no longer undefined. Given the large pot of earmarks distributed, we believe that most members who did not receive any earmarks failed to ask, rather than asked and did not receive, and that for this reason omitting them is the most appropriate strategy. Moreover, for this reason, we do not believe Tobit to be the appropriate estimator. To demonstrate the robustness of this decision, Appendix B of the Supporting Information includes the results of Heckman selection models that include these zeros. Interestingly, there is very little change in the impact of the demand variable across the subcommittees for the outcome equation (amount of earmarks received) and the key substantive findings are not affected significantly. The Supporting Information also includes a set of results mirroring those above but applying the Tobit model. Our results do not appear to be an artifact of specific estimation choices. The Supporting Information file is posted at https:// thedata.harvard.edu/dvn/dv/finocchi.

10. On this point, see Crespin and Finocchiaro (2013) for a more nuanced empirical analysis of the endogeneity problem. For an illustrative discussion of the flurry of last-minute activity surrounding the submission of earmark requests at the committee-defined deadlines, see Pergram (2009).

11. Congressional directories are available at http://www.gpoaccess.gov/cdirectory/ (last accessed January 11, 2014).

12. We thank Gary Jacobson, as always, for supplying his data on election results. 
13. Nevertheless, we examined alternative constructions of this variable - using different thresholds of marginal seats, as well as an ordinal variable — and none affected the substantive results (results reported in Appendix B of the Supporting Information). In addition, we explored the possibility that seniority and competitiveness might have an impact in a more nuanced fashion by using an interaction term. The substantive results were unchanged and this interaction was only significant in two of the subcommittees by party models (in one case it was negative and in one case it was positive). We appreciate the comments of the anonymous reviewers on this issue, one of whom rightly notes that even a null result for this interaction is an interesting finding. As we discuss later in the article, this may be tied up in the changing nature of the appropriations process in Congress.

14. Although studies of earmarks have accounted for district demand to a limited extent-for instance Lee's (2003) study of transportation earmarks incorporates transportation-related measures and Lazarus (2010) considers demand across federal agencies - no study of earmarks has modeled demand directly at the subcommittee level. Another approach has been to include general measures such as district liberalism (Lazarus, 2009) that are unlikely to tap a district's demand for the specific type of government spending encapsulated in legislation produced by each Appropriations subcommittee. Crespin and Rohde (2010) find that voting on appropriations is multidimensional, so standard measures of liberalism and conservatism may not correctly account for district demand for a particular type of earmark.

15. To be clear, if a member did not receive earmarks in either year, this is reflected in two observations.

16. A large share of earmark dollars for this subcommittee is allocated to presidential libraries.

17. David Obey is the only member in our dataset who served in multiple positions as both full chair and cardinal.

18. See, for example, Feehery (2010) and Sanchez and Lesniewski (2012), for a portrayal of the current role of the Appropriations Committees in Congress.

\section{References}

Adler, E. S. (2000). Constituency characteristics and the "guardian" model of appropriations subcommittees, 1959-1998. American Journal of Political Science, 44, 104-114.

Adler, E. S. (2002). Why congressional reforms fail: Reelection and the House committee system. Chicago, IL: University of Chicago Press.

Adler, E. S., \& Lapinski, J. S. (1997). Demand-side theory and congressional committee composition: A constituency characteristics approach. American Journal of Political Science, 41, 895-918.

Aldrich, J. H., \& Rohde, D. W. (1998). The transition to Republican rule in the House: Implications for theories of congressional politics. Political Science Quarterly, $112,541-567$. 
Aldrich, J. H., \& Rohde, D. W. (2000a). The consequences of party organization in the House: The role of the majority and minority parties in conditional party government. In J. R. Bond \& R. Fleisher (Eds.), Polarized politics: Congress and the Presidential in a partisan era (pp. 31-72). Washington, DC: CQ Press.

Aldrich, J. H., \& Rohde, D. W. (2000b). The Republican revolution and the House Appropriations Committee. Journal of Politics, 62, 1-33.

Aldrich, J. H., \& Rohde, D. W. (2001). The logic of conditional party government: Revisiting the electoral connection. In L. C. Dodd \& B. I. Oppenheimer (Eds.), Congress reconsidered (7th ed., pp. 269-292). Washington, DC: CQ Press.

Alvarez, R. M., \& Saving, J. L. (1997). Deficits, democrats, and distributive benefits: Congressional elections and the pork barrel in the 1980s. Political Research Quarterly, 50, 809-831.

Angle, M., \& Koszczuk, J. (Eds.). (2007). CQ's politics in America 2008: The 110th Congress. Washington, DC: CQ Press.

Arnold, R. D. (1990). The logic of congressional action. New Haven, CT: Yale University Press.

Balla, S. J., Lawrence, E. D., Maltzman, F., \& Sigelman, L. (2002). Partisanship, blame avoidance, and the distribution of legislative pork. American Journal of Political Science, 46, 515-525.

Berry, C. R., Burden, B. C., \& Howell, W. G. (2010). The President and the distribution of federal spending. American Political Science Review, 104, 783-799.

Bickers, K. N., \& Stein, R. M. (1996). The electoral dynamics of the federal pork barrel. American Journal of Political Science, 40, 1300-1326.

Buchanan, J. M., \& Tullock, G. (1962). The calculus of consent. Ann Arbor: University of Michigan Press.

Carsey, T. M., \& Rundquist, B. (1999). Party and committee in distributive politics: Evidence from defense spending. Journal of Politics, 61, 1156-1169.

Clemens, A., Crespin, M. H., \& Finocchiaro, C. J. (2013). Pork-barreling in Australian politics: A reconsideration of Leigh. Australian Journal of Political Science, 48, 221-232.

Clemens, A., Crespin, M. H., \& Finocchiaro, C. J. (2015). The political geography of distributive politics. Legislative Studies Quarterly, 40, 111-136.

Cox, G. W., \& Magar, E. (1999). How much is majority status in the U.S. Congress worth? American Political Science Review, 93, 299-309.

Cox, G. W., \& McCubbins, M. D. (1993). Legislative leviathan: Party government in the House. Berkeley: University of California Press.

Cox, G. W., \& McCubbins, M. D. (2005). Setting the agenda: Responsible party government in the U.S. House of Representatives. New York, NY: Cambridge University Press.

Crespin, M. H., \& Finocchiaro, C. J. (2008). Distributive and partisan politics in the U.S. Senate: An exploration of earmarks. In N. W. Monroe, J. M. Roberts \& D. W. Rohde (Eds.), Why not parties? Party effects in the United States Senate (pp. 229-251). Chicago, IL: University of Chicago Press.

Crespin, M. H., \& Finocchiaro, C. J. (2013). Elections and the politics of pork in the U.S. Senate. Social Science Quarterly, 94, 506-529. 
Crespin, M. H., Finocchiaro, C. J., \& Wanless, E. O. (2009). Perception and reality in congressional earmarks. The Forum: A Journal of Applied Research in Contemporary Politics, 7(2), Article 1.

Crespin, M. H., \& Rohde, D. W. (2010). Dimensions, issues, and bills: Appropriations voting on the House floor. Journal of Politics, 72, 976-989.

Edwards, K. M., \& Stewart, C., III. (2006, January). The value of committee assignments in Congress since 1994. Paper presented at the annual meeting of the Southern Political Science Association, Atlanta, GA.

Engstrom, E. J., \& Vanberg, G. (2010). Assessing allocation of pork: Evidence from congressional earmarks. American Politics Research, 38, 959-985.

Evans, D. (2004). Greasing the wheels: Using pork barrel projects to build majority coalitions in Congress. New York, NY: Cambridge University Press.

Feehery, J. (2010, May 12). The appropriations committee: Under assault. The Hill. Retrieved from http://thehill.com/blogs/pundits-blog/lawmaker-news/97419-theappropriations-committee-under-assault

Fenno, R. F. (1966). Power of the purse: Appropriations politics in Congress. Boston, MA: Little, Brown.

Ferejohn, J. A. (1974). Pork barrel politics. Stanford, CA: Stanford University Press.

Ferejohn, J. A. (1986). Logrolling in an institutional context: A case study of food stamp legislation. In G. C. Wright, Jr., L. N. Rieselbach \& L. C. Dodd (Eds.), Congress and policy change (pp. 223-256). New York, NY: Agathon Press.

Finocchiaro, C. J., \& Rohde, D. W. (2008). War for the floor: Partisan theory and agenda control in the U.S. House of Representatives. Legislative Studies Quarterly, 33, 35-61.

Frisch, S. A. (1998). The politics of pork: A study of congressional appropriation earmarks. New York, NY: Garland.

Frisch, S. A., \& Kelly, S. Q. (2011). Cheese factories on the moon: Why earmarks are good for American democracy. Boulder, CO: Paradigm.

Froman, L. (1967). The congressional process. Boston, MA: Little, Brown.

Hulse, C. (2007, December 20). Congress is still pursuing earmarks. New York Times. Retrieved from http://www.nytimes.com/2007/12/20/washington/20earmarks.html

Hurwitz, M. S., Moiles, R. J., \& Rohde, D. W. (2001). Distributive and partisan issues in agriculture policy in the 104th House. American Political Science Review, 95, 911-922.

Kiewiet, D. R., \& McCubbins, M. D. (1985). Congressional appropriations and the electoral connection. Journal of Politics, 47, 59-82.

Kiewiet, D. R., \& McCubbins, M. D. (1991). The logic of delegation: Congressional parties and the appropriations process. Chicago, IL: University of Chicago Press.

Krehbiel, K. (1999). Paradoxes of parties in Congress. Legislative Studies Quarterly, 24, 31-64.

Lazarus, J. (2009). Party, electoral vulnerability, and earmarks in the U.S. House of Representatives. Journal of Politics, 71, 1050-1061.

Lazarus, J. (2010). Giving the people what they want? The distribution of earmarks in the U.S. House of Representatives. American Journal of Political Science, 54, 338-353. 
Lazarus, J., \& Reilly, S. (2010). The electoral benefits of distributive spending. Political Research Quarterly, 63, 343-355.

Lazarus, J., \& Steigerwalt, A. (2009). Different houses: The distribution of earmarks in the U.S. House and Senate. Legislative Studies Quarterly, 34, 347-373.

Lee, F. E. (2000). Senate representation and coalition building in distributive politics. American Political Science Review, 94, 59-72.

Lee, F. E. (2003). Geographic politics in the U.S. House of Representatives: Coalition building and distribution of benefits. American Journal of Political Science, 47, 714-728.

Lee, F. E., \& Oppenheimer, B. I. (1999). Sizing up the Senate: The unequal consequences of equal representation. Chicago, IL: University of Chicago Press.

Leonnig, C. D. (2010, May 15). House Democrat calls out Republicans for defying their party on earmark ban. Washington Post. Retrieved from http://www. washingtonpost.com/wp-dyn/content/article/2010/05/14/AR2010051405535.html

Levitt, S. D., \& Snyder, J. M., Jr. (1995). Political parties and the distribution of federal outlays. American Journal of Political Science, 39, 958-980.

Maass, A. A. (1951). Muddy waters. Cambridge, MA: Harvard University Press.

Manley, J. (1970). The politics of finance. Boston, MA: Little, Brown.

Mayhew, D. R. (1974). Congress: The electoral connection. New Haven, CT: Yale University Press.

Morton, R. (1999). Methods and models. New York, NY: Cambridge University Press.

Pergram, C. (2009, April 5). Official business [Web log post]. The Speaker's Lobby. Retrieved from http://radio.foxnews.com/2009/04/05/official-business/

The pork king keeps his crown. (2008, January 14). New York Times. Retrieved from www.nytimes.com/2008/01/14/opinion/14mon3.html

Riker, W. H. (1962). The theory of political coalitions. New Haven, CT: Yale University Press.

Rohde, D. W. (1991). Parties and leaders in the postreform house. Chicago, IL: University of Chicago Press.

Sanchez, H., \& Lesniewski, N. (2012, December 20). Spending panel loses its luster. Roll Call. Retrieved from http://www.rollcall.com/news/spending_panel_loses its_luster-220343-1.html

Savage, J. D. (1991). Saints and cardinals in appropriations committees and the fight against distributive politics. Legislative Studies Quarterly, 16, 329-347.

Sellers, P. J. (1997). Fiscal consistency and federal district spending in congressional elections. American Journal of Political Science, 41, 1024-1041.

Shepsle, K. A., Van Houweling, R. P., Abrams, S. J., \& Hanson, P. C. (2009). The Senate electoral cycle and bicameral appropriations politics. American Journal of Political Science, 53, 343-359.

Shepsle, K. A., \& Weingast, B. R. (1981). Political preferences of the pork barrel: A generalization. American Journal of Political Science, 25, 96-111.

Shepsle, K. A., \& Weingast, B. R. (1987). The institutional foundations of committee power. American Political Science Review, 81, 85-104. 
Spruiell, S. (2007, June 5). "Earmarks have turned the Congress into an ATM machine": The appropriations chairman wants members to obey. National Review Online. Retrieved from http://www.nationalreview.com/article/221181/ earmarks-have-turned-congress-atm-machine-stephen-spruiell

Stein, R. M., \& Bickers, K. N. (1994). Congressional elections and the pork barrel. Journal of Politics, 56, 377-399.

Stein, R. M., \& Bickers, K. N. (1995). Perpetuating the pork barrel: Policy subsystems and American democracy. New York, NY: Cambridge University Press.

Weingast, B. R. (1979). A rational choice perspective on congressional norms. American Journal of Political Science, 23, 245-263.

Weingast, B. R. (1994). Reflections on distributive politics and universalism. Political Research Quarterly, 47, 319-327.

Weingast, B. R., \& Marshall, W. (1988). The industrial organization of Congress. Journal of Political Economy, 91, 132-163.

Williamson, E. (2007, December 21). Spending bills still stuffed with earmarks: Democrats had vowed to curtail pet projects. Washington Post. Retrieved from www.washingtonpost.com/wp-dyn/content/story/2007/12/21/ ST2007122101879.html

\section{Author Biographies}

Austin Clemens is an Assistant Research Scientist at the Public Policy Research Institute at Texas A\&M University. His research is focused on American political institutions and criminal justice policy. His work has been featured in Legislative Studies Quarterly, Business and Politics, and ESPN Magazine.

Michael Crespin is the Associate Director of the Carl Albert Congressional Studies and Research Center and Associate Professor of Political Science. His research focuses on legislative politics and political geography. His work has appeared in the American Journal of Political Science, the Journal of Politics, and Legislative Studies Quarterly.

Charles J. Finocchiaro is an Associate Professor of Political Science at the University of South Carolina. His research focuses on the role of political parties in legislative politics, as well as various aspects of institutional change in the U.S. Congress, and has been published in outlets such as Legislative Studies Quarterly and Political Research Quarterly. 